\title{
A Study on Awareness of Domestic Solid Waste Management among High School Students.
}

\author{
M.Anitha, \\ M. Sc, M. A, M. Ed, qualified NET, SET Lecturer, Pasha College of Education, Neredmet,Secunderabad.
}

\section{Introduction :}

Education has been used by mankind not only as a conserving agency and a mechanism of social control but also as a creative and regenerative influence to bring about positive changes in existing modes of thinking and living in belief's values, attitudes and customs. Environmental education is an integral process, which deals with man's interrelation ship with his natural and man made surroundings including the relation of population growth, pollution, resources allocation and depletion, conservation, technology and urban and rural planning to the total human environment. Environmental education is intended to promote among citizens the awareness and understanding of the environment, our relationship to it and the concern and responsible action necessary to assure our survival and to improve the quality of life.

Human activity, either domestic or industrial produces waste material to greater or lesser extent always. Problems of waste are generated from human activity. The more advanced is the society economically, the more complex wastes are generated. Day to day activities in the home, offices, commercial establishments and industries produce many kind of solid wastes. Every day sweeping of floors, getting rid of used waste food materials, cleaning the cooking vessels, newspaper, torn clothes, plastic bags broken glass are some of these.

The only way out of the waste problem is to prevent or minimize the generation of waste. Hence, students have to be made aware of 3R's- Reduce, Recycle, Reuse of all the possible items to minimize the generation of waste. Definition of Wastes

Waste can be described as "any substance or object the holder discards, intends to discard or is required to discard", as defined by the Waste Framework Directive.

\section{Classification of Wastes}

The classification of wastes varies and depends country by country. Waste can be divided into many different types. The most common method of classification is by their physical, chemical and biological characteristics.

Solid Waste:-

Solid waste is broadly defined as including non-hazardous industrial, commercial and domestic refuse including household organic trash, street sweepings, hospital and institutional garbage and construction wastes.

\section{Liquid Waste}

These are usually wastewaters. This type of waste may contain high concentration of dissolved salts and metals. Liquid wastes are often classified into two broad types: Sewage and toxic wastes. Generally, there are various types of liquid waste generated in urban centers: human excreta, domestics wastes produced in households, hospital wastes, industrial effluents, agricultural liquid wastes and nuclear wastes. When improperly handled and disposed of, liquid wastes pose a serious threat to human health and the environment because of their ability to enter watershed, pollute ground water and drinking water. (US EPA, 2009)

\section{Sludge}

It is a class of waste between liquid and solid. They usually contain between $3 \%$ and $25 \%$ solid, while the rest of the material is dissolved water.

\section{Hazardous Waste}

Hazardous wastes are wastes which, by themselves or after coming into contact with other wastes, have characteristics, such as chemical reactivity, toxicity, corrosiveness or a tendency to explode, that pose a risk to human health or the environment. Hazardous wastes are generated from a wide range of industrial, commercial, agricultural, and to a much less extent, domestic activities. They may take the form of solids, liquids or sludge's, and can pose both acute and chronic public health and environmental risks. 


\section{Waste Management}

Waste Management is the collection, transport, processing, recycling or disposal, and monitoring of waste materials. The terms usually relates to materials produced by human activity, and is generally undertaken to reduce their effect on health, the environment or aesthetics. Waste Management is also carried out to recover resources from it. Waste management can involve solid, liquid, gaseous or radioactive substances, with different methods and fields of expertise for each.

\section{Domestic solid waste production}

Day to day activities in the home, offices, commercial establishments and industries produce many kinds of solid wastes. Every day sweeping of floors, getting rid of used waste food materials, cleaning the cooking vessels, newspaper, torn clothes plastic bags, broken glass are some of these. Depending on the economic condition people either throw away materials or sell them to waste material buyers, in our country. In many middle-income group families, reuse of many materials is a common practice. This habit reduces the waste volume. The following may be in urban domestic wastes: Kitchen wastes, Paper wastes, Metals, Glass, Leather/Rubber, Plastics, Ashes and inert matter

The house refuge consists of ashes, cinders, rubbish, debris from demolition of structure, vegetable peels, seeds, bad vegetables and rotting food materials, wastes of animal origin feathers, bones, flesh, egg shells and others. The waste from kitchen is called Garbage. The street refuge includes the road sweepings, leaves, materials thrown away by people like cigarette buts/match boxes, fruit peels, ground nut shells, paper envelops, waste materials thrown away as useless .Domestic wastes have three main characteristics: Weight generated, density and constituents. These vary according to country and even towns within a country, depending on the extent of industrialization. The range of weight generated per person per day varies between 250 to $1000 \mathrm{gm}$ worldwide density varies from $100 \mathrm{Kg} / \mathrm{cu} . \mathrm{m}$ to $600 \mathrm{Kg} / \mathrm{cu} . \mathrm{m}$. Volume also therefore varies from $1 / 2$ litre to 10 litres per person per day. The important constituents of domestic wastes are

\begin{tabular}{|l|l|}
\hline Vegetable putrescible matter & $20 \%-75 \%$ \\
\hline Inert matter & $5 \%-40 \%$ \\
\hline Paper & $2 \%-60 \%$ \\
\hline Glass & $0 \%-10 \%$ \\
\hline Metals & $0 \%-15 \%$ \\
\hline
\end{tabular}

Waste generation and life style- The waste generation rates of people is directly related to their economic condition. People in richer countries produce more garbage than those in poorer countries.

\section{Harmful effects of domestic solid waste}

The heaps of solid waste make the surroundings dirty. They destroy the natural beauty and damage the landscape.With time it would affect the flora and fauna of these areas as well. Insects and rodents that proliferate in garbage dumps can transmit plague, typhoid, cholera, skin diseases and even malaria and filaria with the breeding of mosquitoes in rain water stagnations in garbage dumps and waste water stagnations in choked up drains. Garbage dumps contribute to the seepage of toxic metals and other chemicals to ground water and surface water. Such contaminations have been linked up with increases in cancer incidences. Garbage add up to air pollution that gains easy entry into lungs and the blood stream. Damages also include fire hazards, foul smells, unsightliness, additional dredging costs of water ways, silting up of reservoirs, decrease in plant productivity, corrosion of structures and structural foundations and depreciation of land value.

Modes of waste Disposal.

\begin{tabular}{|c|c|}
\hline Type of Waste & Techniques of waste disposal \\
\hline Most domestic solid waste & Used as landfills in urban area \\
\hline $\begin{array}{l}\text { Some solid waste like plastics, metals, and papers. } \\
\text { Plastic bags, bowls, buckets, mugs, dishes plates, } \\
\text { tables etc } \\
\text { - Scrap metal }\end{array}$ & $\begin{array}{l}\text { Can be sent for recycling } \\
\text { These materials can be taken up for recycling so that they can be } \\
\text { reused. } \\
\text { Metal can be melted and recycled into solid metal again. }\end{array}$ \\
\hline $\begin{array}{l}\text { 3.Most domestic waste containing biodegradable organic waste } \\
\bullet \quad \text { Cow dung }\end{array}$ & $\begin{array}{l}\text { Can be used to prepare manure for plants } \\
\text { Can be used to prepare biogas. }\end{array}$ \\
\hline
\end{tabular}

Domestic solid waste management involves managing activities associated with generation, collection transport and disposal of solid waste in an environmentally-compatible manner, adopting principles of economic, aesthetics, energy and conservation. 


\section{Management of solid wastes.}

There are three types of disposal techniques practiced in domestic solid wastes. The three main practical methods used are Land disposal,Composting and Incineration.

\section{Methods of Land Disposal}

Simple dumping the solid waste at the out skirts of the city in low lying areas, or on either side of the road at the out skirts is very common. Uncontrolled tipping is the word used for such kind of disposal . The heap attracts rats, snakes and other seekers of hide outs. The rotting organic matter emits stinking smells.Flies and other insects breed with complete freedom. Prior to any treatment, recovery of materials that have resale value or materials that can be converted to some useful materials should be done. Glass bottles, good or broken are made into glass powder to be used as abrasive on the sides of the match boxes. Some glass materials can be melted and made again into glass bottles. Rubber tyres are used to make crude shoes/chappals or made into granules to be mixed in making roads. Fuel gas is generated from rubber materials. Tin and iron have re-sale value. Paper is reused by making it into pulp and hand made card boards or hand made paper. Papiermâché is a man made paper pulp from which beautiful statues and art objects are made.

\section{Composting}

Under natural conditions dead vegetables and animal materials decompose under the influence of bacteria and fungi, where they fall and add to the fertility of the soil. In many places farmers have depended on organic manure derived from agricultural wastes and vegetation. Kitchen wastes and garden wastes in domestic solid wastes is of biodegradable nature.

Compost is a biological process. Microorganisms in soil use biodegradable organic matter as food. Composting has three products: compost as an organic fertilizer, salvaged materials for resale and non compostable as land fill materials. The aim of composting is to convert a major portion of solid wastes into marketable product.

Compost is brownish, peaty material, the main constituent of which is humus. When compost is applied to soil it lightens heavy soil, improves the texture of light sandy soil, increases water retention and enlarges root systems of plants. It makes available additional plant nutrients since it contain $\mathrm{N}, \mathrm{P}$ and $\mathrm{K}$ percentage being $\mathrm{N}=1.2 \%, \mathrm{P}=0.7 \%$ and $\mathrm{K}=1.2 \%$. This composition varies with material that is used for composting. When compost is used with artificial fertilizers it makes the phosphorus more readily available and prolongs the period over which the nitrogen is available, thus improves nutrient take- up by plants. All trace elements needed by plants are available in compost. The environment gets enriched for plant growth.

Incineration: Volume of waste can be reduced by burning it at very high temperature in an incinerator. In the agricultural farms, small scale incineration takes place. It is a common sight to see small fires of burning dry leaves, paper etc. On the side of roads. Such fires produce considerable smoke and air pollution. Even though these fires are small, a number of such fires add up to the total air pollution. Any city refuse cannot be economically subjected to incineration. Since the combustion has to be maintained by the amount of volatile organic matter. In many cases fuel may have to be subsidized and the operation becomes expensive.

\section{Significance Of The Study}

Education system alone is a powerful medium to ensure environmental protection. It reaches most parts of the population at a young age and more environmental friendly behavior can be practical on daily basis by making the students aware of the importance of waste management.

The present paper is an attempt to create awareness to students regarding waste management, waste prevention and importance of 3 R's - Reduce, Reuse, and Recycle.

\section{Objective Of The Study}

For the study of awareness of Domestic solid waste management among high school students of Ranga Reddy District, Quthbullapur Mandal, the following objectives were framed.

- To study the awareness of Domestic solid waste management among the high school students.

- To compare the awareness among government and private high school students.

- To compare the awareness among urban and rural students of high school.

- To compare the awareness among girls and boys of high school.

\section{Hypothesis Of The Study}

These hypothesis were formulated based on the objectives.

- There is no significant difference in awareness of Domestic solid waste management between government and private high school students . 
- There is no significant difference in awareness of Domestic solid waste management between urban and rural students of high school.

- There is no significant difference in awareness of Domestic solid waste management between high school girls \& boys.

\section{Methodology}

The study was designed as a descriptive survey .In this study, stratified random sampling technique was used, 4 schools were selected from Quthbullapur Mandal, RangareddyDistrict.Of these two of the schools were in rural area and two in urban area. 100 students of class VIII were selected , 50 from rural and 50 from urban which included 25 girls and 25 boys from each area.

\section{Tool Used ;}

The tool to be administered was prepared by the researcher which was a Questionnaire of 25 questions with multiple choice.

\section{Reliability And Validity Of The Tool:}

Reliability:

Reliability of the tool was determined by test retest method. The same tool was administered to a group of subjects twice at an interval of two weeks and the two sets of scores were correlated to obtain a correlation coefficient which was the index of reliability.

\section{Validity:}

Face validity: For establishing face validity the final form of the tool was shown to 7 expert teachers educators and their reactions regarding format and language of the tool were sought. All the teacher educators were satisfied with the language and format of the questionnaire so it was decided that the scale has face validity.

Content Validity: At the stage of planning questionnaire regarding the awareness of domestic solid waste management was taken into consideration which consists of 25 items. These 25 items were used to measure the awareness of domestic solid waste management. Experts have suggested all the 25 items, so the final form of the tool represented the contents evenly and equally. Hence it can be said on logical basis that the tool has proper content validity.

\section{Analysis Of Data}

Objective-I To know the awareness on Domestic solid waste management among the high school students of Quthbullapur mandal, Rangareddy District.

Awareness of Domestic solid waste management by whole sample

\begin{tabular}{|l|l|l|}
\hline Variable & Sample Size & $\%$ of Awareness \\
\hline High school students & 100 & 39.52 \\
\hline
\end{tabular}

As per the above table, it is clear that the awareness on Domestic solid waste management among the high school students of Quthbullapur mandal, Ranga Reddy District is very low.

Objective- II To compare the awareness of Domestic solid waste management between government and private high school students.

Awareness of Domestic solid waste management between government and private high school students

\begin{tabular}{|l|l|l|l|l|l|l|}
\hline Variable & Sample size & mean & Std Dev & $\begin{array}{l}\text { Mean } \\
\text { difference }\end{array}$ & SED & Critical Ratio \\
\cline { 1 - 5 } Government & 50 & 45.12 & 10.79 & 13.44 & 2.01 & 6.68 \\
\cline { 1 - 5 } Private & 50 & 31.68 & 9.22 & & & \\
\hline
\end{tabular}

As per the above table, the calculated ' $t$ ' value is more than ' $t$ ' value at 0.05 and 0.01 levels of significance. So we reject the null hypothesis that there is no significant difference in the awareness of government and private school students about domestic solid waste management.

The awareness of domestic solid waste management is more in government school students compared to private school students.

Objective-III. To compare the difference between Urban and Rural students of high school on the awareness of Domestic solid waste management. 
A Study On Awareness Of Domestic Solid Waste Management Among High School Students.

Awareness of Domestic solid waste management between urban and rural high school students

\begin{tabular}{|l|l|l|l|l|l|l|}
\hline Variable & Sample size & mean & Std Dev & $\begin{array}{l}\text { Mean } \\
\text { difference }\end{array}$ & SED & Critical Ratio \\
\cline { 1 - 4 } Urban & 50 & 42.72 & 15.71 & 5.76 & 2.70 & 2.13 \\
\hline Rural & 50 & 36.96 & 10.81 & & & \\
\hline
\end{tabular}

As per the above table the calculated ' $t$ ' value is less than ' $t$ ' value at 0.01 level of significance which is 2.58 . So we accept the null hypothesis that there is no significant difference in the awareness of Domestic solid waste management between Urban and Rural area students of high school.

Objective-IV To compare the difference between Boys and Girls of high school on the awareness of Domestic solid waste management.

Awareness of Domestic solid waste management between boys and girls of high school.

\begin{tabular}{|l|l|l|l|l|l|l|}
\hline Variable & Sample size & mean & Std Dev & $\begin{array}{l}\text { Mean } \\
\text { difference }\end{array}$ & SED & Critical Ratio \\
\hline Boys & 50 & 41.68 & 13.67 & 3.84 & 2.73 & 1.41 \\
\hline girls & 50 & 37.84 & 13.62 & & & \\
\hline
\end{tabular}

As per the above table the calculated' $t$ ' value is less than ' $t$ ' value at 0.05 level of significance which is 1.96. So we accept the null hypothesis that there is no significant difference in awareness of Domestic solid waste management among boys and girls of high school.

Findings:

The main findings of the research study are

- The awareness on Domestic solid waste management among high school students is very low in Quthbullapur mandal, Rangareddy District.

- The awareness on Domestic solid waste management among the government high school students is more compared to private high school students.

- There is no significant difference in awareness on Domestic solid waste management among the high school students of urban and rural area.

- There is no significant difference in awareness on domestic solid waste management among boys and girls of high school.

\section{Suggestions}

- The government should create global awareness to the increasing problem of Domestic Solid Waste Management through environmental education in schools as well as community.

- The government should introduce collaboration programmes with school students in order to enable them to find the generation and collection of waste in and around schools surroundings.

- From the primary level itself the importance of segregation of waste, reduction and prevention should be inculcated in the students.

- The multiple benefits of recycling should be made aware through means of communication. Eg. Making paper from waste pulp rather than virgin pulp saves $50 \%$ energy. Every ton of recycled glass saves energy equal to 100 litres of oil.

- Environmental Education should enable the students to acquire new skills for controlling Domestic Waste and new ways of garbage disposal.

- The students should be encouraged to implement the 3R's of waste management-Reduce, Reuse and Recycle.

- The schools should equip the students with most efficient methods for the Domestic Waste Management and also to implement them.

- The schools should enable the students to learn about the dangers of the different types of Domestic Waste in the community and in the environment. This will enable them to minimize the effect of waste in the community.

\section{Educational Implications Of The Study}

The study has provided enhancing and enriching knowledge regarding the various aspects of Waste Management, prevention of Waste and reduction of waste. In a way it provided the preliminary background and base work for pollution control to a certain extent. 
- This study helps to take up special and necessary activities regarding segregation of waste.

- The study enables the educational planners to revise the contents on environmental education and throw light on consequences of growing waste.

- The study reveals the greater awareness that widespread use of plastics is a problem because many plastics are non-biodegradable.

- The study also shows that -Human activities generate many categories of wastes, each with its own characteristics and disposal problems.

- The study enabled to analyze that the only way out of the waste problem is to prevent or minimize the generation of waste.

\section{Reference}

[1]. AGARWAL, SHAMMI PUROHIT (2004), Environmental Sciences, Shyam Printers, Jodhpur

[2]. ANJANEYULU (2005), Introduction to Environmental Sciences, BS Publication, Hyderabad.

[3]. ANJI REDDY M. (2007), Environmental Sciences and Technology, BS Publication, Hyderabad.

[4]. ERACH BHARUCHA (2005), Environmental studies, University press, Delhi.

[5]. JAGDISH CHAND (2007), Environmental Education, An shah Publishing House, Delhi

[6]. JOHN BEST . W, JAMES KAHN.V (2006), Research in Education, Prentice hall publication, New Delhi

[7]. KOTHARI.C.R. (2004), Research Methodology, New age international Publishers, New Delhi.

[8]. MANGAL S.K (2006) Statistics in Psychology and Education, Prentice hall of India, New Delhi.

[9]. MURALI KRISHNA Dr. K.V.S.G (2006) Glimpses of Environment, VGS Publication, Vijayawada.

[10]. RAJAGOPALAN.R (2007), Environmental Studies, Oxford Universities, New Delhi.

[11]. SURESH K. DHAMEJA Dr. (2007) Environmental Science, Kat aria \& Sons, Delhi. 